\title{
MANAGEMENT OF ENDOCRINE DISEASE Hyperandrogenic states in women: pitfalls in laboratory diagnosis
}

\author{
Michel Pugeat ${ }^{1,2,3}$, Ingrid Plotton ${ }^{2,4}$, Aude Brac de la Perrière', Gérald Raverot ${ }^{1,2}$, \\ Henri Déchaud ${ }^{1,2}$ and Véronique Raverot ${ }^{4}$
}

${ }^{1}$ Fédération d'Endocrinologie, Groupement Hospitalier Est, Hospices Civils de Lyon, Bron, France, ²Université Claude Bernard Lyon 1, Lyon, France, '3NSERM U1060 Institut CarMen, Lyon, France, and 'Laboratoire d'Hormonologie, d’Endocrinologie Moléculaire et des Maladies Rares, Groupement Hospitalier Est, Hospices Civils de Lyon, Bron, France
Correspondence should be addressed to M Pugeat

Email

michel.pugeat@chu-lyon.fr

\begin{abstract}
Measuring total testosterone level is the first-line approach in assessing androgen excess in women. The main pitfalls in measuring testosterone relate to its low concentration and to the structural similarity between circulating androgens and testosterone, requiring accurate techniques with high specificity and sensitivity. These goals can be achieved by immunoassay using a specific anti-testosterone monoclonal antibody, ideally after an extraction step. Liquid chromatography coupled to tandem mass spectrometry (LC-MS/MS) will be commonly used for measuring testosterone, providing optimal accuracy with a low limit of detection. Yet, the pitfalls of these two techniques are well identified and must be recognized and systematically addressed. In general, laboratories using direct testosterone immunoassay and mass spectrometry need to operate within a quality framework and be actively engaged in external quality control processes and standardization, so as to ensure appropriate interpretation irrespective of the particular laboratory. Circulating testosterone is strongly bound to sex-hormone-binding globulin (SHBG), and SHBG levels are typically low in overweight hyperandrogenic patients. Thus, low SHBG may decrease circulating testosterone to normal values, which will mask androgen excess status. One way to avoid this pitfall, awaiting direct free testosterone assays that are yet to be developed, is to measure SHBG and calculate free testosterone. A few other pitfalls will be discussed in this review, including those of adrenal androgen exploration, with the aim of helping clinicians to better handle laboratory investigation of androgen excess disorders in women.
\end{abstract}

Invited Author's profile

Michel Pugeat is currently Emerit Professor, University Claude Bernard, Lyon, France. The main areas of Prof. Pugeat's research is on sex steroid hormones and their binding proteins with the original description of phenotypes associated to $C B G / S H B G$ gene mutations and the evidence that SHBG/CBG levels are associated with metabolic syndrome and its inherent risks for developing chronic diseases. His research specifically focuses on the laboratory investigation of polycystic ovary syndrome (PCOS) emphasizing that SHBG does influence the clinical interpretation of total testosterone. He has undertaken prospective research on the endocrine disrupter bisphenol A (BPA) and in developing a highly sensitive BPA immunoassay that has been a useful tool for investigation of disease related to environment. His current interest is on the influence of androgens on sexual arousal and their deviance in males.

(C) 2018 European Society of Endocrinology Printed in Great Britain
Published by Bioscientifica Ltd.

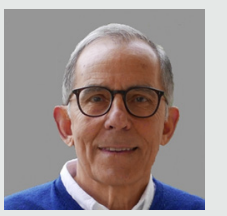




\section{Introduction}

Hyperandrogenic states are the clinical manifestation of excess androgen disorder in women. They encompass excess androgen production associated with exceptional androgen-secreting tumors, rare genetic diseases that impair adrenal steroidogenesis, and the very common polycystic ovary syndrome (PCOS) $(1,2,3,4,5,6)$. Hyperandrogenic states also include increased peripheral androgen metabolism and clearance that enhance androgen cell availability and bioactivity $(7,8)$. Finally, they may also involve increased androgen activity within the cell, through active intracellular metabolism and/or enhanced androgen receptor machinery (9). Overall prevalence of hyperandrogenic states is significant, at $6-12 \%$ worldwide $(10,11)$ and raises the question of how laboratory investigations should be conducted for diagnosis $(12,13,14)$.

Endocrine diseases are typically suspected on clinical symptoms, a combination of which suggests excess or deficient hormonal secretion and/or action. Excessive or deficient endocrine gland activity is associated with activation or inhibition of the specific regulatory system maintaining endocrine function homeostasis and/or limiting the consequences of surplus or deficiency in the considered hormone (15). This robust paradigm of feedback regulation assumes that it is usually possible to identify most endocrine disorders by measuring hormones from thyroid, adrenal and gonadal sources and their specific pituitary regulatory factors, in blood, saliva or urine samples or even within cells. However, although this paradigm is well adapted to laboratory thyroid investigation, balancing thyroid hormone (T4/T3) and thyroid-stimulating hormone (TSH) data, it is less consistent when applied to female androgen disorder: changing hormonal profile during the menstrual cycle, the positive rather than negative feedback of estradiol regulation on luteinizing hormone (LH) regulation and the inhibitory effect of androgens on LH inhibitory regulation of progesterone have been puzzling for consensual recommendations on how to evaluate gonadotropin profile in androgen excess women $(16,17)$.

This review will challenge the concept that androgen investigation can accurately identify the origin of hyperandrogenic states in females, by identifying the pitfalls and how to circumvent them so as finally to succeed in diagnosis.

\section{Consensus and recommendations for the diagnostic approach to hyperandrogenic states}

Hyperandrogenic state is identified on excessive hair growth with a male pattern (hirsutism) and is suspected in patients with recurrent acne with seborrhea or androgenetic alopecia (9). Rapid onset of virilizing symptoms such as voice masculinization, abnormal muscle development and clitoris enlargement are suggestive of rare androgensecreting tumors and must be promptly identified $(5,9)$.

Most consensus statements recommend measuring total testosterone as first-line investigation of hyperandrogenic states (Figure 1). These include the $1990 \mathrm{NIH}$-sponsored conference on PCOS $(2,14)$, the Rotterdam ESHRE/ASRM-sponsored PCOS consensus workshop group (3), the Androgen Excess and PCOS Society (4), the French Endocrine Society Consensus (13) and the PCOS Special Interest Group of the European Society of Endocrinology (18).

Is total testosterone the relevant hormone for identifying hyperandrogenic states? Testosterone circulates in the blood, loosely bound to albumin but tightly and specifically bound to sex hormone-binding globulin (SHBG). According to the law of mass action, a small steroid fraction is protein-unbound and available for target cells; in women, this fraction is less than $2 \%$, while the albumin-bound complex is $41 \%$ and the SHBG-bound complex is 57\% (19). There is no definitive

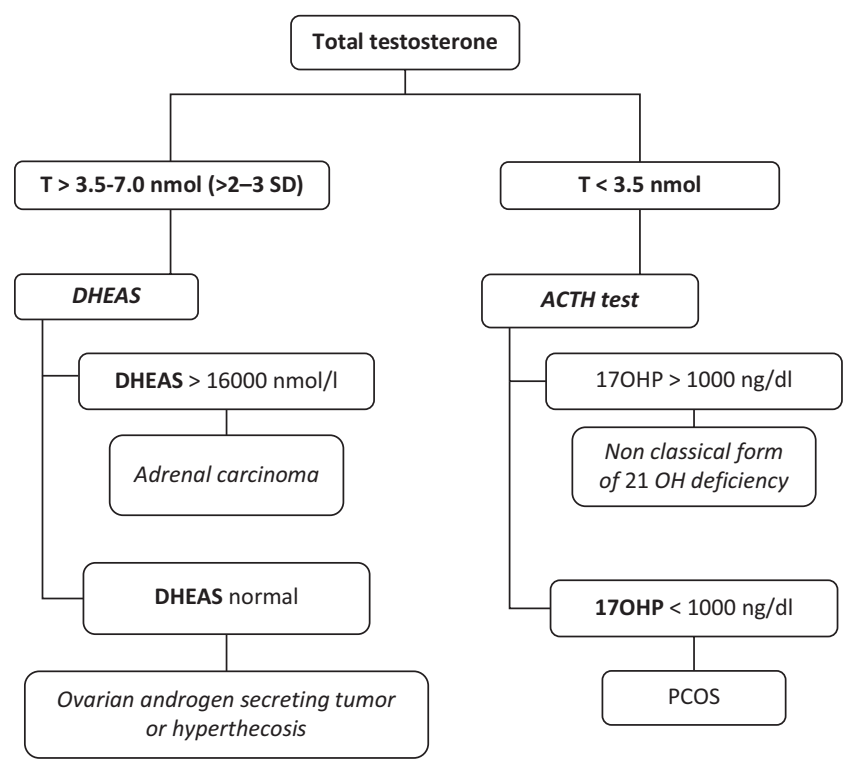

Figure 1

Paradigm for identifying androgen excess in women. 
evidence for a specific transit of the SHBG-bound steroid complex, although it has been shown that SHBG, by interacting with megalin, the main endocytic receptor (20), may provide a specific pathway for cellular uptake of biologically active SHBG-bound androgens and estrogens. This has been reported for trophoblastic cell lines and might be an important pathway for androgen transport to the placenta for aromatization during pregnancy. Moreover, human SHBG is found in human breast and prostate cancer cells (21) and, by interacting with fibulin, a matrix-associated protein, can be sequestered from the blood into the stromal matrix of the uterine endometrium (22). Taken together, these intriguing findings challenge the free-hormone hypothesis (see below).

The rationale for measuring testosterone is essentially based on the assumption that testosterone is the main active circulating androgen. Testosterone has a strong 'media profile' for the public, students and physicians. It is primarily produced as an androgen precursor: androstenedione from thecal cells and dehydroepiandrosterone (DHEA) from the adrenal cortex (23), which are converted into testosterone, especially in adipose tissue. The production rate (PR) of testosterone, including direct ovarian secretion and peripheral metabolism from both ovarian and adrenal precursors, maintains circulating testosterone concentration. Conversely, the metabolic clearance rate (MCR), defined as the volume of blood cleared irreversibly per unit of time, is the main process decreasing circulating androgen concentrations. The strong binding affinity of SHBG to dihydrotestosterone, testosterone and estradiol (in decreasing order of magnitude (19)) is inversely correlated to their respective MCRs, which are 315, 485 and $720 \mathrm{~L} /$ day respectively $(23,24,25,26)$. In contrast, DHEA and androstenedione show low binding affinity and bind weakly to SHBG, with much higher MCRs of 2200 and 1200 L/day respectively (Table 1 ).

\section{Pitfalls in measuring total testosterone by direct immunoassay}

Testosterone level is poorly correlated with the severity of hirsutism. This point has been documented using a reference testosterone assay (27). Severely hirsute patients may have normal testosterone levels, suggesting high androgen sensitivity or increased testosterone clearance. Conversely, the Rotterdam consensus (3) pointed out that patients with polycystic ovarian morphology on ultrasound may show increased testosterone levels without increased hair growth or recurrent acne.
Table 1 Half-life $\left(T^{1 / 2}\right)$, metabolic clearance rate (MCR) and binding affinity constant at $37^{\circ} \mathrm{C}$ according to Longcope et al. (23, 24), Mahoudeau et al. (25) and Dunn et al. (19).

\begin{tabular}{|c|c|c|c|}
\hline & $\boldsymbol{T}^{1 / 2}(\min )$ & MCR (L/day) & $\begin{array}{c}\text { SHBG binding } \\
\text { affinity* }\end{array}$ \\
\hline Dihydrotestosterone & 53 & 315 & 5.5 \\
\hline Testosterone & 34 & 485 & $1.2-1.3$ \\
\hline Estradiol & ND & 720 & 0.7 \\
\hline Androstenedione & 50 & 2200 & 0.03 \\
\hline Dehydroepiandrosterone & 60 & 2040 & 0.07 \\
\hline
\end{tabular}

${ }^{*} \mathrm{~K}_{\mathrm{a}}: 10^{-9} \times \mathrm{M}^{-1}$ at $37^{\circ} \mathrm{C}$

Variations in testosterone levels over the menstrual cycle are fairly insignificant. Although it is recommended that testosterone be measured in the early follicular phase, in practice, blood sampling in fasting conditions at any time of day or point in the cycle is effective for measuring testosterone.

Low testosterone concentration and the structural similarity between circulating androgens and testosterone require accurate and sensitive techniques (28). This can be achieved by competitive immunoassays that rely on the inherent ability of an antibody to bind small molecules. To assay testosterone, antibodies are developed that match its particular structure, at the price of their specificity, as the configuration of testosterone is similar to that of other circulating androgens. An extraction step, using an organic solvent, followed by purification of the extract by chromatography (Celite, HPLC, Sephadex LH20), eliminates steroids likely to interfere with the immunological reaction because of their similar structure and/or insufficient antibody specificity $(12,13)$. Steroid extraction also eliminates much of the matrix effect, mainly related to steroid transport proteins (albumin and SHBG).

Precision and specificity are mainly dependent on the quality of the antibodies used to capture testosterone and on the technique used to reveal the antibody-bound testosterone complex.

The low limit of detection or sensitivity of the immunoassay is in part dependent on the labeled probe and the system used to immobilize the immune complex. The chief markers are radioactive (iodine 125 and tritium), enzymatic (HRP and PAL), fluorescent (europium) and chemiluminescent. Steroid immunoassays using timeresolved fluorometric detection of europium (Delfia Technology) usually exhibit higher sensitivity than tritiated or enzyme-conjugated tracers, and challenge immunoassays using 125-iodine-labeled steroids, with the advantages of a stable non-radioactive tracer (29). 
Table 2 Main advantages, disadvantages and pitfalls with direct immunoassay.

Advantages
- RIAs and chemiluminescence immunoassays are the most
- Eidely used methods ( $>80 \%$ of labs)
- Suitable for automated platforms that reduce the risk of
- Puman error
- Increased effort by manufacturers to calibrate their assays

In addition, immunoassays exploit the high-affinity streptavidin-biotin system by incorporating the small biotin molecule in enzymes or in the hormone to be measured. The high binding affinity $\left(K_{\mathrm{a}}=10^{15}\right)$ of streptavidin for biotin and biotinylated compounds is exploited to immobilize immune complexes in the solidphase matrix. This approach has considerably enhanced the precision of immunometric assays.

Nowadays, chemiluminescence and fluorescence are the major detection principles in modern automated analyzers, whereas radioactive systems are less widely used. The main advantages, disadvantages and pitfalls of measuring testosterone by direct immunoassay are listed in Table 2 .

\section{Novel pitfalls associated with advances in hormone immunoassay}

Hormone immunoassays using the streptavidin-biotin system can be affected by high levels of circulating biotin, leading to a risk of misdiagnosis. This risk of false diagnosis has long been recognized for thyroid diseases $(30,31,32,33)$. Biotin (vitamin B7) is a water-soluble vitamin with a recommended daily intake (RDI) in the order of milligrams per day. High-dose biotin (10 000 times the RDI) is currently indicated to improve clinical outcome and quality of life in patients with progressive multiple sclerosis. An excess of biotin in the blood sample, by competition with the trace of biotinylated hormone or the biotinylated specific antibody, depending on the system used, will bind to streptavidin-coated microparticles in the solid phase and interfere with the signaling system, leading to over- or under-estimation. To overcome this pitfall, it has been shown that adsorption of biotin in magnetic streptavidin-coated microparticles efficiently eliminates biotin interference, when included in assays kits (34). A potential benefit has been claimed for biotin treatment in various diseases, including alopecia and diabetes mellitus, and patients may sometimes use biotin as a complementary medicine. In these conditions, false high results for testosterone and DHEAS have been reported (33), but this remains to be further documented.
Disadvantages and pitfalls

- Low accuracy

- Lack of specificity, which depends on the quality of testosterone antibodies

- Potential interference with binding proteins

- Potential interference and matrix effects, despite good specificity of the antibodies used

- Unexpected interference: e.g., biotin

\section{Measuring testosterone by mass spectrometry: a must}

This chapter refers to comprehensive reviews $(35,36$, $37,38,39,40)$ that readers are encouraged to consult for more information on mass spectrometry principles, components and software.

Gas chromatography (GC) coupled with MS was the initial analytical approach for simple molecularmass-selective detection and is the reference method for measuring testosterone $(35,36)$. GC-MS requires a large blood sample $(>2 \mathrm{~mL})$ for a step of extraction and derivatization. The development of liquid chromatography (LC) and the emergence of atmospheric pressure chemical ionization and of electrospray ionization has allowed direct coupling of LC and MS. LC-MS constitutes a remarkable progress, since the eluent phase is liquid, making derivatization unnecessary for measuring most steroids, including testosterone, which possess unsaturated carbonyls that are readily ionized without derivatization.

The introduction of tandem MS, which involves coupling 2 quadrupole mass filters with an interposed collision cell to reveal the fragmentation pattern of target steroids, has greatly increased the selectivity of LC-MS. Presently, LC-MS/MS offers the best quality for steroid measurement. It has substantially improved our current approach to and understanding of congenital steroid metabolism disorders, including 21-hydroxylase deficiency (37).

Although LC-MS/MS is not widely used in laboratories in Europe, because the high cost of the equipment, the special expertise required and the time-consuming procedure make large series of assays impractical, it may in the near future be suitable for routine use, as costs decrease, becoming an alternative to immunoassay when automated analysis platforms are available.

Ultra-performance liquid chromatography (UPLC) is now enhancing analysis speed, sensitivity and resolution (38). The precision and accuracy of LC-MS/MS and its low limits of detection argue for it being the reference for assessing androgen status in women and children $(28,36)$. 


\section{Pitfalls in measuring testosterone by mass spectrometry}

Application of LC-MS/MS should provide accurate measurement of total testosterone levels. Yet, pitfalls must be recognized and systematically addressed (38, 39). The selectivity of MS/MS detection was originally overestimated. The inaccuracy of LC-MS/MS methods may be related to the ionization process and matrix effects with differential influence on target analytes and internal standard compounds. Most potential sources of inaccuracy can be controlled by sufficient LC separationbased sample workup before MS analysis.

Finally, important sources of unreliable results include human error, the risk of which can likely be minimized by automated clinical chemistry analyzers. Only a few commercial LC-MS/MS assay kits are presently available, and their instrument configurations are extremely still heterogeneous. Automating the LC-MS/MS processes, with the final goal of developing fully automated MS/MS-based analyzer systems, is not only a prerequisite for more widespread use of this powerful technology in clinical laboratories but also essential to increase reliability. The main advantages and drawbacks of LC-MS/MS for measuring testosterone are listed in Table 3.

\section{Current recommendations for total testosterone assay}

The current position advocates appropriate use of both immunoassay and mass spectrometry-based methods for measuring total testosterone for the diagnosis of hyperandrogenic states in women. This realistic approach was defended by Taylor et al. (40), echoing Franz Kafka's philosophy: 'Start with what is right rather than what is acceptable'. With this aim in view, LC-MS/MS allows highly accurate analyses with enhanced specificity. However, pitfalls must be recognized and addressed, and they equally echo Voltaire's maxim that 'The best is the enemy of good', arguing that replacing all immunoassays by MS technology would be 'an unrealistic and unnecessary goal', because the availability of MS is limited by cost and technical demands. Recommendations for measuring testosterone can realistically be founded on this attitude. An ultimate consensus will be possible when MS equipment becomes available all around the world $(3,4,13,18)$.

\section{The free-hormone hypothesis}

The free-hormone hypothesis $(41,42)$ states that the protein-unbound or free circulating hormone fraction is bioactive. There is good evidence that free-hormone concentration reflects the clinical situation more accurately than total plasma hormone level. This concept has been widely developed for routine investigation of thyroid function, to allow for changes in thyroid hormone-binding globulin (TBG) level, notably during pregnancy and under oral contraception.

Similar considerations should be applied to SHBG, the main transport system for testosterone and estradiol, which modulates their bioactivity by restrictive diffusion into target tissue. The free-hormone hypothesis has been re-validated on a mouse model overexpressing hSHBG (43). In this model, a remarkable increase in circulating SHBG was associated with prolonged half-life of SHBG-bound testosterone and consequently increased testosterone concentration. In contrast, free testosterone was essentially unchanged, likely the consequence of adaptive feedback regulation with a significant increase in LH level. Nevertheless, male transgenic mice exhibited a mild hypogonadal phenotype that was possibly due to low bioavailability of sex steroid hormone to target cells, as shown using tritium-labeled probes. These results strongly substantiate the concept that a key physiological function of SHBG is to maintain testosterone levels and to regulate cell bioavailability. This model is translatable to human male physiology, where feedback regulation of gonadotropin maintains free testosterone levels within the normal range.

In women, however, androgens show minimal if any negative feedback regulation of LH secretion (44). In

Table 3 Main advantages vs disadvantages and pitfalls with LC-MS/MS for measuring testosterone.

Advantages
- Accuracy
sigh specificity owing to its ability to
interest (parent ion) and to fragment
the parent ion into specific, smaller ions
(daughter ions)
- Sensitivity
- Potential for simultaneous measurement
of several different steroids

Disadvantages and pitfalls

- Expensive equipment

- Technical demands

- Variability between labs (risk of human error, automata are not yet available)

- Technical pitfalls: high degree of variation in the efficiency of atmospheric pressure ionization, standardization mandatory, 'isotope effects' of internal standards, differential impact of matrix effects on analyte and isotope internal standard, interference from in-source transformation of conjugate metabolites, isobaric congeners, matrix compounds sharing mass transitions, etc. 
contrast, the positive feedback regulation of LH pulsatile secretion by estradiol, observed in the late follicular phase (44), may increase LH levels and maintain androgen excess. This is especially the case in patients with low SHBG, which contributes per se to clinical hyperandrogenism. It is well documented that insulin resistance (45), liver lipogenesis and/or inflammation $(46,47)$ decrease SHBG levels by a well-identified mechanism in the liver expression of SHBG gene. In addition, it is also documented that androgen excess reduces the inhibition of gonadotropin-releasing hormone pulse frequency normally exerted by progesterone, causing rapid LH pulse secretion and further maintaining or increasing ovarian androgen production (48). Thus, increased LH secretion maintains high ovarian androgen production, in a vicious circle that was early described by Samuel Yen (49). The current concept is that androgen excess promotes abnormal neuroendocrine LH secretion, which in turn perpetuates the hyperandrogenic state (48). It is noteworthy that administration of flutamide, a non-steroid androgen receptor blocker, has essentially no effect on gonadotropin regulation in normal women (50) but restores some progesterone feedback sensitivity in adolescent PCOS subjects, with decreased LH pulsatility (51).

\section{Measuring or calculating free testosterone concentration}

According to the free-hormone hypothesis, measuring the protein-unbound fraction of testosterone provides a better index of overall production and a marker of biological activity $(41,42)$. The technical challenge is to develop a methodology that does not disturb the binding equilibrium between steroids and binding proteins, and accurate and highly sensitive assays for measuring the free concentration, which is much lower than total testosterone.

Equilibrium dialysis has long been the standard method to separate protein-bound from free testosterone prior to quantification (52) and is considered to provide the best estimate of free testosterone plasma concentration, despite technical difficulties (53). By adding a trace of ${ }^{3} \mathrm{H}$-testosterone to the serum sample, with an appropriate incubation time at $37^{\circ} \mathrm{C}$, the SHBG- and albumin-bound testosterone fractions can be separated from the free testosterone through a membrane in a small dialysis tube or chamber. This method allows measurement of the percentage of free ${ }^{3} \mathrm{H}$-testosterone, which is usually $2-3 \%$ of the total testosterone circulating in the blood. It also allows measurement of the actual concentration of free testosterone in the dialysate, using a reliable testosterone assay. It requires highly purified radioactive $3 \mathrm{H}$-testosterone as tracer $(54,55)$.

Centrifugal ultrafiltration dialysis has been validated and found to be faster, with fewer technical requirements than equilibrium dialysis (56). A reference method, coupling ultrafiltration to GC-MS detection, has been recently developed (57) with further improvement in analytical sensitivity, convenience and sample requirements when coupled with LC-MS/MS (58).

Awaiting routine availability of these promising techniques, clinicians must bear in mind that the current commercially available immunoassays for free testosterone show inadequate accuracy and precision (59).

\section{Surrogate methods to calculate free testosterone concentration}

Calculation of free testosterone from testosterone and SHBG concentrations using accurate assays has been claimed to be a reliable approach for routine clinical practice (60). Using the laws of mass action, it provides a surrogate for direct free testosterone measurement, but is dependent on the equation that is used $(61,62)$. The calculation assumes that there is no inter-individual variability in SHBG-binding affinity and that albumin concentrations and albumin-binding affinity for testosterone are constant. It also considers that interaction with endogenous ligands that may significantly displace testosterone from SHBG-binding sites is negligible. Various derived testosterone calculations to estimate free testosterone have been proposed, including a free testosterone index (FTI), defined as the ratio of total testosterone to SHBG, expressed as a percentage. Theoretically, FTI corresponds to free testosterone when the molar ratio of total testosterone to SHBG is low, which is the case in women but not in adult men $(61,62)$. In general, calculated values for free testosterone correlate well with equilibrium dialysis results $(60,63)$.

Pitfalls in calculating free testosterone should be recognized. SHBG gene polymorphism, associated with change in SHBG-binding affinity, has been identified (64) and one study reported an effect of SHBG concentration on apparent affinity (65). More importantly, the Dunn model of the binding equilibrium of natural endogenous ligands (19) provides evidence that potential SHBG binders, such as drugs or endocrine disrupters, may disturb SHBG-binding sites and consequently the freehormone fraction (66).

Bioavailable testosterone encompasses albumin-bound and SHBG-bound testosterone and has been claimed to 
be the bioavailable fraction of circulating testosterone for target cells (67). The use of saturated ammonium sulfate to precipitate the globulins, including SHBG, before centrifugation to separate SHBG-bound ${ }^{3} \mathrm{H}$-testosterone from albumin-bound plus free ${ }^{3} \mathrm{H}$-testosterone, has been reported to be effective in a few laboratories (68). A major limitation of the ammonium sulfate precipitation assay method is incomplete precipitation of globulins, including SHBG, which may increase intra- and interassay variability. With some technical precautions, nonSHBG-bound testosterone is a reliable instrument for routine evaluation of androgen excess $(69,70)$.

\section{Free vs total testosterone in hyperandrogenic patients}

Most studies reported in the literature calculated free testosterone from total testosterone, SHBG or albumin, according to Vermeulen et al. (53). In a consecutive population of clinically hyperandrogenic patients, Azziz et al. (71) reported that overall total testosterone was elevated in $38 \%$ of cases, while for free testosterone was increased in 55.5\%; in this study, one-fifth of patients had normal androgen levels. In a consecutive series of hirsute patients, Carmina et al. (72) reported PCOS on the Rotterdam criteria in two-thirds of patients, total testosterone being the most commonly elevated androgen; free testosterone was similarly discriminating for PCOS diagnosis, but not superior. Interestingly, one study showed that serum SHBG levels showed good sensitivity and specificity (87\%) for diagnosis of PCOS (73). Using a MS-based technique, Stener-Victorin et al. reported that free testosterone concentration was useful for PCOS diagnosis, but that estrone concentration, alone or in combination to elevated free testosterone, was more discriminating (74).

\section{Alternative approach: measuring androstenedione}

O'Reilly et al. (75) reported, in PCOS patients on the Rotterdam criteria, that high testosterone levels correlated with high androstenedione and free androgen index; however, high androstenedione level was a more sensitive marker in PCOS-related androgen excess. They also reported a strong negative association between serum androstenedione and insulin sensitivity, and a high incidence of glucose intolerance correlating with the severity of the androgen phenotype. Interestingly, Lerchbaum et al. (76) reported that elevated free testosterone, unlike isolated androstenedione elevation, was associated with an adverse metabolic phenotype.
Thecombination of totaltestosterone, androstenedione and free testosterone provides good accuracy for diagnosis of PCOS and its hyperandrogenemic sub-phenotypes $(76,77,78)$. However, application for predicting metabolic risk in PCOS needs further investigation (79).

\section{Adrenal androgen excess investigation}

The adrenal cortex produces DHEA in the zona reticularis under the control of adrenocorticotropic hormone (ACTH), with no evidence of negative feedback regulation of pituitary ACTH secretion by DHEA. DHEA has a short half-life of $\sim 50 \mathrm{~min}$, with high clearance of $2040 \mathrm{~L} /$ day (80). A significant portion of DHEA is sulfated through the action of DHEA sulfotransferase (81). DHEAS is strongly bound to albumin and is cleared from the circulation at a very slow rate of $12.8 \mathrm{~L} /$ day, with a long half-life of $\sim 17 \mathrm{~h}$ (80). Consequently, in women, DHEAS concentration is relatively stable throughout the day (82). DHEAS is the precursor of active androgens and can be taken up by ovarian follicles to synthesize testosterone (83) and even converted into dihydrotestosterone in peripheral tissues once converted to androstenedione, without requiring prior formation of testosterone (84).

DHEA production varies with aging and starts decreasing after 30 years (85), with no change in ACTH secretion. This aging profile of androgen secretion might be associated to decline activity in selected enzymatic activities, such as cytochrome-b5-dependent 17,20 lyase (CYP17), in the reticularis zone of the adrenal gland (85), but remains to be further investigated. SULT2A1 is the major enzyme responsible for DHEA sulfation in the adrenal glands and liver. The sulfate donor PAPS is required for sulfotransferase activity. In humans, PAPS is synthesized by the two isoforms of PAPS synthase, PAPSS1 and PAPSS2. Sulfation of DHEA to DHEAS is the major pathway of DHEA metabolism, suggesting that increased DHEA sulfation may limit the amount of DHEA available for androgen synthesis. By contrast, mutations of the gene encoding human PAPS synthase 2 (PAPSS2) have been reported in patients with very low DHEAS levels but increased androgen levels. This represents one monogenic adrenocortical cause of androgen excess (86).

\section{Immunoassay for DHEAS measurement}

Since DHEAS is a water-soluble antigen present in human plasma in large quantities (around $6 \mu \mathrm{mol} / \mathrm{L}$ in young subjects), immunoassay is performed on plasma sample with or without dilution, depending on the method 
used (radioimmunoassay, automated immunoassay with a non-radioactive marker, etc.). Using highly specific antibodies renders interference from other steroids very unlikely, given the typical concentration (12).

\section{DHEAS in hyperandrogenic states}

Approximately 20-30\% of hyperandrogenic and/or PCOS women show excess adrenal androgen production (AAP) when DHEAS is used as a marker of AAP (87). Hirsute patients with high DHEAS levels may show a PCOS-like phenotype. Inherited defects in the enzymes responsible for abnormal steroidogenesis account for only a very small portion of patients with increased DHEA/DHEAS. In contrast, many PCOS patients under ACTH stimulation display a generalized increase in the adrenal steroid production with no evidence of hypothalamic-pituitary axis dysfunction (88). In vivo studies have reported that insulin amplifies adrenal steroidogenesis in response to ACTH in PCOS $(88,89)$, which is consistent with in vitro data $(90,91)$. In an opposite way, metformin (92) and thiazolidinedione treatment decrease DHEAS levels in correlation with decreased insulin resistance and hyperinsulinemia in PCOS patients $(93,94)$. Studies in monkeys agree with these findings (95), although there are also some contrasting results in the field (96).

Regarding the influence of ovarian androgens on the secretion of adrenal androgens, the effect of testosterone is controversial in both in vivo and in vitro studies (97); in PCOS, it was concluded that ovarian androgens, and particularly testosterone, have only limited impact on adrenocortical function (87). Preliminary results from the MEDIGENE study support the concept that some genes associated with insulin resistance may be associated with excess AAP (98).

\section{Screening for nonclassical congenital adrenal hyperplasia (NCAH) in hyperandrogenic states}

Most if not all guidelines suggest that diagnosis of $\mathrm{NCAH}$ should be ruled out in hirsute and PCOS patients based on morning plasma 17-hydroxyprogesterone (17OHP) levels, optimally sampled during the first stage of the cycle. Basal $17 \mathrm{OHP}$ level should be assessed in the absence of or well after any glucocorticoid treatment that might cause false negative results. The largest multicenter trial, reported by Moran et al. (99), showed that baseline 17OHP level above $10 \mathrm{ng} / \mathrm{mL}$ is a sensitive criterion for NCAH diagnosis; in agreement with a more recent single-center study (100), morning baseline $17 \mathrm{OHP}<2 \mathrm{ng} / \mathrm{mL}$ was associated with $8 \%$ false negatives: i.e., patients with genetically proven NCAH. To enhance screening efficiency, an ACTH challenge test has been developed, using $250 \mu$ g cosyntropin. With a $>10 \mathrm{ng} / \mathrm{mL}$ cut-off, Morel and Tardy (101) showed that nearly $100 \%$ of patients with genetically proven NCAH, regardless of the type of mutation, could be identified. This very accurate cut-off value is routinely used for NCAH screening in hyperandrogenic women $(102,103$, $104,105,106)$. In the near future, the development of sequencing platforms should enable routine sequencing of the CYP21A2 gene.

\section{Perspectives in assessing hyperandrogenic states}

\section{The identification of androgen metabolites}

Dihydrotestosterone, which is generated from testosterone by $5 \alpha$-reductase, and its major glucuronidated androgen metabolites have been measured by MS (74). They could provide significant comprehensive profiles that merits to be further investigated. Interestingly, DHEAS was found to be a strong independent predictor of glucuronidated androgen in PCOS patients (74).

The identification of 11-oxygenated steroids with androgenic activity, and especially the recent characterization of 11-keto-testosterone and 11-ketodihydrotestosterone, challenges the paradigm that testosterone is the main potent natural androgen (107). In addition, the abundance of adrenal C19 steroid $11 \beta$-hydroxyandrostenedione (11OHA4) as a precursor of 11-oxygenated steroids, and the development of ultraperformance convergence chromatography-tandem mass spectrometry (UPC2-MS/MS) for their analysis, have opened up new perspectives for understanding androgen excess disorders (108). O'Reilly et al. (109) elegantly showed that 11-oxygenated androgens constitute the majority of circulating androgens in women with PCOS and that obese PCOS women have higher 11OHA4 levels than nonobese PCOS women, who show close correlation between 11OHA4 and metabolic disorder markers (BMI, fasting insulin and Homa index). The direct influence effect of insulin that increases the androgen-activating enzyme aldo-ketoreductase type 1 C3 (AKR1C3) expression, together with the lipogenic effects of androgens reported in PCOS women open new fields of investigation for establishing the mutual influence of androgen excess on metabolic dysfunctions in women (110). 


\section{Main recommendations for laboratory investigation of hyperandrogenic states}

Assay standardization is crucial for correct interpretation of results. Progress has been achieved through the introduction of homogeneous hormone standards. However, many automated methods for determination of steroid hormones do not provide satisfactory results. Interpretation requires knowledge of normal concentration ranges and deviations in a population of normal women free of ovarian or metabolic disorder $(111,112)$.

\section{External quality assessment (EQA) of hormone assays}

Since the 1980s, the trend has been for in-house assays to be superseded by automated assays, and this places a special responsibility on manufacturers to ensure reliable assay design and calibration. Since the 1980s, the trend has been for in-house assays to be superseded by commercial automated assays, and this places a special responsibility on manufacturers to ensure reliable assay design and calibration as well as for the hospital laboratories to validate the analytical performance of these assays.

Obviously, the infrastructure and management of hospitals and health care systems vary according to national policies and accreditation system. Ensuring correct implementation is a multidisciplinary responsibility involving clinicians, laboratory staff, manufacturers of diagnostic systems and healthcare regulators. All these professional groups therefore have an interest in external quality assessment (EQA). EQA is an audit tool that can identify the improvements required to reduce the risk of inaccurate hormone assessment that are of central importance for the diagnosis of endocrine disease (112). EQA has been undertaken in several countries, including France since 1977 by a Lyon-based association of biologists (ProBioQual) (13). Participating laboratories receive lyophilized control sera 6 times per year, for assay of numerous analytes, including testosterone. Analysis of results obtained over time has prompted a number of observations. The vast majority of laboratories (over 95\%) carrying out total testosterone are using in routine various immunoassays without prior extraction or purification. There is considerable scatter in control serum values exhibiting concentrations close to those found in women. This variation is due to differences between assay kits and to the lack of precision of most assay kits at these concentration levels. Scatter decreases with increasing control sample concentration and becomes acceptable for concentrations comparable to those found in men (13).
The limitations of testosterone assays were summarized in a position statement by the Endocrine Society (28), and a CDC Hormone Standardization Project has been promoted $(113,114,115)$. Table 2 lists the pros and cons of direct testosterone immunoassay.

\section{Decision-tree for evaluating the origin of androgen excess founded on a single total testosterone assay}

Where testosterone is 2-fold higher than the upper normal limit (or $>2$ s.D. of the mean normal range), it is suggestive of an androgen-secreting tumor. In this case, DHEAS must be measured. DHEAS level $>600 \mu \mathrm{g} / \mathrm{dL}$ indicates androgen-secreting adrenal carcinoma (often associated with hypercorticism). In unusual circumstances, dexamethasone test to suppress androgens arising from a functional adrenal source and gonadotropin-releasing hormone (GnRH) agonist could be helpful, in identifying ovarian androgen-secreting tumor and hyperthecosis.

Where testosterone is just above the upper normal limit, the most likely diagnosis is PCOS. However, screening for the nonclassic form of 21-hydroxylase deficiencies should be performed (17OH-progesterone assay on basal or ACTH-stimulated conditions) and, depending on the clinical setting, Cushing disease should be ruled out. Lastly, $\Delta 4$-androstenedione has been studied comparatively with testosterone, and dissociations have been reported in patients having isolated elevation of androstenedione but no elevation of testosterone particularly in case of reduced SHBG concentration that is essentially associated to metabolic syndrome.

\section{Remarks in conclusion}

Increased total testosterone level is the main indicator of hyperandrogenic states in women. By its high accuracy, mass spectrometry provides the best tool for measuring testosterone. There is debate on how to measure free testosterone, which has the advantage of taking account of the fact that SHBG, the main testosterone transport protein, is low in many circumstances, including overweight, insulin resistance and moderate inflammatory state. However, a recent review challenged the hormonefree hypothesis and its interpretation and proposed a multi-step dynamic allosteric model of testosterone's binding to SHBG assuming variability of SHBG-binding affinity and crystallography data showing that each SHBG homodimer binds two testosterone molecules rather than one (116). This concept is yet to be independently verified. 
One alternative would be to measure only SHBG as a marker for these disorders, which play a part, notably in the pathophysiology of PCOS. The most exciting perspective could be to access to the complete profile of androgen precursors as well as metabolites by using performances of MS, not only in the blood but also in urine and various tissues. This future would open a new domain in the comprehension and treatment of androgen excess disorders in women.

\section{Declaration of interest}

The authors declare that there is no conflict of interest that could be perceived as prejudicing the impartiality of this review.

\section{Funding}

This research did not receive any specific grant from any funding agency in the public, commercial or not-for-profit sector.

\section{References}

1 Stein IF \& Leventhal ML. Amenorrhea associated with bilateral polycystic ovaries. American Journal of Obstetrics and Gynecology 1935 29 181-191. (https://doi.org/10.1016/S0002-9378(15)30642-6)

2 Zawadzki JK \& Dunaif A. Diagnostic criteria for polycystic ovary syndrome: towards a rational approach. In Polycystic Ovary Syndrome, pp 377-384. Eds A Dunaif, JR Givens, FP Haseltine \& GR Merriam. Boston: Blackwell Scientific Publications, 1992.

3 The Rotterdam ESHRE/ASRM-Sponsored PCOS Consensus Workshop Group. Revised 2003 consensus on diagnostic criteria and long-term health risks related to polycystic ovary syndrome (PCOS). Human Reproduction 200419 41-47. (https://doi.org/10.1093/humrep/ deh098)

4 Azziz R, Carmina E, Dewailly D, Diamanti-Kandarakis E, EscobarMorreale HF, Futterweit W, Janssen OE, Legro RS, Norman RJ, Taylor AE et al. The androgen excess and PCOS society criteria for the polycystic ovary syndrome: the complete task force report. Fertility and Sterility 200991 456-488. (https://doi.org/10.1016/j. fertnstert.2008.06.035)

5 Escobar-Morreale HF, Carmina E, Dewailly D, Gambineri A, Kelestimur F, Moghetti P, Pugeat M, Qiao J, Wijeyaratne CN, Witchel SF et al. Epidemiology, diagnosis and management of hirsutism: a consensus statement by the Androgen Excess and Polycystic Ovary Syndrome Society. Human Reproduction Update 2012 18 146-170. (https://doi.org/10.1093/humupd/dmr042)

6 Legro RS, Arslanian SA, Ehrmann DA, Hoeger KM, Murad MH, Pasquali R \& Welt CK. Diagnosis and treatment of polycystic ovary syndrome: an Endocrine Society clinical practice guideline. Journal of Clinical Endocrinology and Metabolism 201398 4565-4592. (https:// doi.org/10.1210/jc.2013-2350)

7 Rosenfield RL. Plasma free androgen patterns in hirsute women and their diagnostic implications. American Journal of Medicine 197966 417-421. (https://doi.org/10.1016/0002-9343(79)91061-1)

8 Vermeulen A, Verdonck L, Straeten MV \& Orie N. Capacity of the testosterone-binding globulin in human plasma and influence of specific binding of testosterone on its metabolic clearance rate. Journal of Clinical Endocrinology and Metabolism 196929 1470-1480. (https://doi.org/10.1210/jcem-29-11-1470)
9 Rosenfield RL. Clinical practice. Hirsutism. New England Journal of Medicine 2005353 2578-2588. (https://doi.org/10.1056/ NEJMcp033496)

10 Asuncion M, Calvo RM, San Millan JL, Sancho J, Avila S \& EscobarMorreale HF. A prospective study of the prevalence of the polycystic ovary syndrome in unselected Caucasian women from Spain. Journal of Clinical Endocrinology and Metabolism 200085 2434-2438.

11 Johnstone EB, Rosen MP, Neril R, Trevithick D, Sternfeld B, Murphy R, Addauan-Andersen C, McConnell D, Pera RR \& Cedars MI. The polycystic ovary post-Rotterdam: a common, age-dependent finding in ovulatory women without metabolic significance. Journal of Clinical Endocrinology and Metabolism 201095 4965-4972. (https://doi.org/10.1210/jc. 2010-0202)

12 Stanczyk FZ. Diagnosis of hyperandrogenism: biochemical criteria. Best Practice and Research Clinical Endocrinology and Metabolism 2006 20 177-191. (https://doi.org/10.1016/j.beem.2006.03.007)

13 Pugeat M, Dechaud H, Raverot V, Denuziere A, Cohen R \& Boudou P. Recommendations for investigation of hyperandrogenism. Annals of Endocrinology 201071 2-7. (https://doi.org/10.1016/j. ando.2009.12.007)

14 Final Report National Institute of Health. Evidence-based methodology workshop on polycystic ovary syndrome December 3-5, 2012 executive summary. (available at: http://prevention.nih. gov/workshops/2012/pcos/resourc-es.aspx)

15 Melemed S, Polonsky KS, Reed Larsen P \& Kronenberg HM. Williams Textbook of Endocrinology, 13th Edition: Principles of Endocrinology. Elsevier, 2016

16 Yen SS, Vela P \& Rankin J. Inappropriate secretion of follicle stimulating hormone and luteinizing hormone in polycystic ovarian disease. Journal of Clinical Endocrinology and Metabolism 197030 435-442. (https://doi.org/10.1210/jcem-30-4-435)

17 Eagleson CA, Gingrich MB, Pastor CL, Arora TK, Burt CM, Evans WS $\&$ Marshall JC. Polycystic ovarian syndrome: evidence that flutamide restores sensitivity of the gonadotropin-releasing hormone pulse generator to inhibition by estradiol and progesterone. Journal of Clinical Endocrinology and Metabolism 200085 4047-4052.

18 Conway G, Dewailly D, Diamanti-Kandarakis E, Escobar-Morreale H, Franks S, Gambineri A, Kelestimur K, Macut D, Micic D, Pasquali R et al. The polycystic ovary syndrome: a position statement from the European Society of Endocrinology. European Journal of Endocrinology 2014171 1-29. (https://doi.org/10.1530/EJE-14-0253)

19 Dunn JF, Nisula BC \& Rodbard D. Transport of steroid hormones: binding of 21 endogenous steroids to both testosterone-binding globulin and corticosteroid-binding globulin in human plasma. Journal of Clinical Endocrinology and Metabolism 198153 58-68. (https://doi.org/10.1210/jcem-53-1-58)

20 Hammes A, Andreassen TK, Spoelgen R, Raila J, Hubner N, Schulz H, Metzger J, Schweigert FJ, Luppa PB, Nykjaer A et al. Role of endocytosis in cellular uptake of sex steroids. Cell 2005122 751-762. (https://doi.org/10.1016/j.cell.2005.06.032)

21 Hammond GL. Molecular properties of corticosteroid binding globulin and the sex-steroid binding proteins. Endocrine Review 1990 11 65-79. (https://doi.org/10.1210/edrv-11-1-65)

$22 \mathrm{Ng} \mathrm{KM}$, Catalano MG, Pinos T, Selva D, Avvahumov GV, Munelle F \& Hammond GL. Evidence that fibulin family members contribute to the steroid-dependent extravascular sequestration of sex hormonebinding globulin. Journal Biological Chemistry 2006281 15853-15861. (https://doi.org/10.1074/jbc.M512370200)

23 Longcope C. Adrenal and gonadal androgen secretion in normal females. Journal of Clinical Endocrinology and Metabolism 198615 213-228. (https://doi.org/10.1016/S0300-595X(86)80021-4)

24 Longcope C, Layne DS \& Tait JF. Metabolic clearance rates and interconversions of estrone and $17 \beta$-estradiol in normal males and females. Journal of Clinical Investigation 196847 93-106. (https://doi. org/10.1172/JCI105718) 
25 Mahoudeau JA, Bardin CW \& Lipsett MB. The metabolic clearance rate and origin of plasma dihydrotestosterone in man and its conversion to the $5 \alpha$-androstanediols. Journal of Clinical Investigation 197150 1338-1344. (https://doi.org/10.1172/JCI106613)

26 Saez JM, Forest MG, Morera AM \& Bertrand J. Metabolic clearance rate and blood production rate of testosterone and dihydrotestosterone in normal subjects, during pregnancy, and in hyperthyroidism. Journal of Clinical Investigation 197251 1226-1234 (https://doi.org/10.1172/JCI106917)

27 Legro RS, Schlaff WD, Diamond MP, Coutifaris C, Casson PR, Brzyski RG, Christman GM, Trussel JC, Krawetz SA, Snyder PJ et al. Total testosterone assays in women with polycystic ovary syndrome: precision and correlation with hirsutism. Journal of Clinical Endocrinology and Metabolism 201095 5305-5313. (https://doi. org/10.1210/ jc.2010-1123)

28 Rosner W, Auchus RJ, Azziz R, Sluss PM \& Raff H. Position statement: utility, limitations, and pitfalls in measuring testosterone: an Endocrine Society position statement. Journal of Clinical Endocrinology and Metabolism 200792 405-413. (https://doi.org/10.1210/jc.20061864)

29 Fiet J, Giton F, Fidaa I, Valleix A, Galons H \& Raynaud JP. Development of a highly sensitive and specific new testosterone time-resolved fluoroimmunoassay in human serum. Steroids 200469 461-471. (https://doi.org/10.1016/j.steroids.2004.04.008)

30 Elston MS, Sehgal S, Du Toit S, Yarndley T \& Conaglen JV. Facticious Graves' disease due to biotin immunoassay interference - a case and review of the literature. Journal of Clinical Endocrinology and Metabolism 2016101 3251-3255. (https://doi.org/10.1210/jc.20161971)

31 Piketty ML, Polak M, Flechtner I, Gonzales-Briceño L \& Souberbielle JC. False biochemical diagnosis of hyperthyroidism in streptavidin-biotin-based immunoassays: the problem of biotin intake and related interferences. Clinical Chemistry Laboratory Medicine 201755 780-788. (https://doi.org/10.1515/cclm-2016-0606)

32 Kummer S, Hermsen D \& Distelmaier F. Biotin treatment mimicking Graves' disease. New England Journal of Medicine 2016375 704-706. (https://doi.org/10.1056/NEJMc1602096)

33 Trambas CM, Sikaris KA \& Lu ZX. More on biotin treatment mimicking Graves' disease. New England Journal of Medicine 2016375 1698-1699. (https://doi.org/10.1056/NEJMc1611875)

34 Piketty MP, Prie D, Sedel F, Bernard D, Hercend C, Chanson PH $\&$ Souberbielle JC. High-dose biotin therapy leading to false biochemical endocrine profiles: validation of a simple method to overcome biotin interference. Clinical Chemistry Laboratory Medicine 201755 817-835.

35 Krone N, Hughes B, Lavery G, Stewart PM, Arlt W \& Shackleton CH. Gas chromatography/mass spectrometry (GC/MS) remains a preeminent discovery tool in clinical steroid investigations even in the era of fast liquid chromatography tandem mass spectrometry (LC/ MS/MS). Journal of Steroid Biochemistry and Molecular Biology 2010121 496-504. (https://doi.org/10.1016/j.jsbmb.2010.04.010)

36 Stanczyk FZ \& Clarke NJ. Advantages and challenges of mass spectrometry assays for steroid hormones. Journal of Steroid Biochemistry and Molecular Biology 2010121 491-495. (https://doi. org/10.1016/j.jsbmb.2010.05.001)

37 Keevil BG. Novel liquid chromatography tandem mass spectrometry (LC-MS/MS) methods for measuring steroids. Best Practice Research Clinical Endocrinology and Metabolism 201327 663-674. (https://doi. org/10.1016/j.beem.2013.05.015)

38 Kulle A, Krone K, Holterhus PM, Schuler G, Greaves RF, Juul A, de Rijk YB, Hartman MF, Saba A, Hiort O et al. Steroid hormone analysis in diagnosis and treatment of DSD: position paper of EU COST Action BM 1303 'DSDnet'. European Journal of Endocrinology 2017176 P1-P9. (https://doi.org/10.1530/EJE-16-0953)

39 Vogeser M \& Seger CH. Pitfalls associated with the use of Liquid chromatography-Tandem mass spectrometry in the clinical laboratory. Clinical Chemistry 201056 1234-1244. (https://doi. org/10.1373/clinchem.2009.138602)

40 Taylor AE, Keevil B \& Huhtaniemi IT. Mass spectrometry and immunoassay: how to measure steroid hormones today and tomorrow. European Journal of Endocrinology 2015173 D1-D12. (https://doi.org/10.1530/EJE-15-0338)

41 Pardridge WM. Selective delivery of sex steroid hormones to tissues in vivo by albumin and by sex hormone-binding globulin. Annals of the New-York Academy of Sciences 1988538 173-192. (https://doi. org/10.1111/j.1749-6632.1988.tb48863.x)

42 Mendel CM. The free hormone hypothesis: a physiologically based mathematical model. Endocrine Review 198910 232-274. (https://doi. org/10.1210/edrv-10-3-232)

43 Laurent MR, Hammond GL, Blokland M, Jardí F, Antonio L, Dubois V, Khalil R, Sterk SS, Gielen E, Decallonne B et al. Sex hormone-binding globulin regulation of androgen bioactivity in vivo: validation of the free hormone hypothesis. Scientific Reports 20166 35539. (https://doi.org/10.1038/srep35539)

44 Couzinet B \& Schaison G. The control of gonadotrophin secretion by ovarian steroids. Human Reproduction 19938 (Supplement 2) 97-101. (https://doi.org/10.1093/humrep/8.suppl_2.97)

45 Pugeat M, Crave JC, Elmidani M, Nicolas MH, Garoscio-Cholet M, Lejeune H, Dechaud H \& Tourniaire J. Pathophysiology of sex hormone binding globulin (SHBG): relation to insulin. Journal of Steroid Biochemistry and Molecular Biology 199140 841-849. (https:// doi.org/10.1016/0960-0760(91)90310-2)

46 Selva DM, Hogeveen KN, Innis SM \& Hammond GL. Monosaccharide-induced lipogenesis regulates the human hepatic sex hormone-binding globulin gene. Journal of Clinical Investigation 2007117 3979-3987.

47 Simó R, Sáez-López C, Barbosa-Desongles A, Hernández C \& Selva DM. Novel insights in SHBG regulation and clinical implications. Trends in Endocrinology and Metabolism 201526 376-383. (https://doi.org/10.1016/j.tem.2015.05.001)

48 Burt Solorzano CB, McCartney CHR, Blank SK, Knudsen KL \& Marshall JC. Hyperandrogenemia in adolescent girls: origins of abnormal GnRH secretion. British Journal of Obstetrics and Gynecology 2010117 143-149. (https://doi.org/10.1111/j.14710528.2009.02383.x)

49 Yen SSC. The polycystic ovary syndrome. Clinical Endocrinology 1980 12 177-207. (https://doi.org/10.1111/j.1365-2265.1980.tb02132.x)

50 Couzinet B, Thomas G, Thalabard JC, Brailly S \& Schaison G. Effect of a pure antiandrogen on gonadotropin secretion in normal women and in polycystic ovarian disease. Fertility and Sterility 198952 42-50. (https://doi.org/10.1016/S0015-0282(16)60786-0)

51 De Leo V, Lanzetta D, D'Antona D, La Marca A \& Morgante G. Hormonal effects of flutamide in young women with polycystic ovary syndrome. Journal of Clinical Endocrinology and Metabolism 1998 83 99-102. (https://doi.org/10.1210/jcem.83.1.4500)

52 Forest MG, Rivarola MA \& Migeon CJ. Percentage binding of testosterone, androstenedione and dehydroisoandrosterone in human plasma. Steroids 196812 323-343. (https://doi. org/10.1016/0039-128X(68)90025-1)

53 Vermeulen A, Stoica T \& Verdonck L. The apparent free testosterone concentration, an index of androgenicity. Journal of Clinical Endocrinology and Metabolism 197133 759-767. (https://doi. org/10.1210/jcem-33-5-759)

54 Miller KK, Rosner W, Lee H, Hier J, Sesmilo G, Schoenfeld D, Neubauer G \& Klibanski A. Measurement of free testosterone in normal women and women with androgen deficiency: comparison of methods. Journal of Clinical Endocrinology and Metabolism 200489 525-533. (https://doi.org/10.1210/jc.2003-030680)

55 Sinha-Hikim I, Arver S, Beall G, Shen R, Guerrero M, Sattler F, Shikuma C, Nelson JC, Landgren BM, Mazer NA et al. The use of a sensitive equilibrium dialysis method for the measurement of free testosterone levels in healthy, cycling women and in human 
immunodeficiency virus-infected women. Journal of Clinical Endocrinology and Metabolism 199883 1312-1318. (https://doi. org/10.1210/jcem.83.4.4718)

56 Hammond GL, Nikser JA, Jones LA \& Siiteri PK. Estimation of the percentage of free steroid in undiluted serum by centrifugal ultrafiltration- dialysis. Journal of Biological Chemistry 1980255 5023-5026.

57 Chen Y, Yazdanpanah M, Wang XY, Barry R, Hoffman BR, Eleftherios P, Diamandis EP \& Wong PY. Direct measurement of serum free testosterone by ultrafiltration followed by liquid chromatography tandem mass spectrometry. Clinical Biochemistry 201043 490-496. (https://doi.org/10.1016/j. clinbiochem.2009.12.005)

58 Salameh WA, Redor-Goldman MM, Clarke NJ, Reitz RE \& Caulfiel MP. Validation of a total testosterone assay using high-turbulence liquid chromatography tandem mass spectrometry: total and free testosterone reference ranges. Steroids 201075 169-175. (https://doi. org/10.1016/j.steroids.2009.11.004)

59 Rosner W. An extraordinarily inaccurate assay for free testosterone is still with us. Journal of Clinical Endocrinology and Metabolism 200186 2903-2905. (https://doi.org/10.1210/jcem.86.6.7643)

60 Vermeulen A, Verdonck L \& Kaufman JM. A critical evaluation of simple methods for the estimation of free testosterone in serum. Journal of Clinical Endocrinology and Metabolism 199984 3666-3672. (https://doi.org/10.1210/jcem.84.10.6079)

61 Ly LP \& Handelsman DJ. Empirical estimation of free testosterone from testosterone and sex hormone-binding globulin immunoassays. European Journal of Endocrinology 2005152 471-478. (https://doi. org/10.1530/eje.1.01844)

62 Sartorius G, Ly LP, Sikaris K, McLachlan R \& Handelsman DJ. Predictive accuracy and sources of variability in calculated free testosterone estimates. Analytical Clinical Biochemistry 200946 137-143. (https://doi.org/10.1258/acb.2008.008171)

63 Faix JD. Principles and pitfalls of free hormone. Measurements Best Practice and Research Clinical Endocrinology and Metabolism 201327 631-645. (https://doi.org/10.1016/j.beem.2013.06.007)

64 Ohlsson C, Wallaschofski H, Lunetta KL, Stolk L, Perry JR, Koster A, Petersen AK, Eriksson J, Lehtimäki T, Huhtaniemi IT et al. Genetic determinants of serum testosterone concentrations in men. PLoS Genetics 20117 e1002313. (https://doi.org/10.1371/journal. pgen.1002313)

65 Heinrich-Balard L, Zeinyeh W, Déchaud H, Rivory P, Roux A, Pugeat M \& Cohen R. Inverse relationship between hSHBG affinity for testosterone and hSHBG concentration revealed by surface plasmon resonance. Molecular and Cellular Endocrinology 2015399 201-207. (https://doi.org/10.1016/j.mce.2014.10.002)

66 Pugeat M, Dunn JF \& Nisula BC. Transport of steroid hormones: interaction of 70 drugs with testosterone-binding globulin and corticosteroid-binding globulin in human plasma. Journal of Clinical Endocrinology and Metabolism 198153 69-75. (https://doi. org/10.1210/jcem-53-1-69)

67 Pardridge WM. Serum bioavailability of sex steroid hormones. Journal of Clinical Endocrinology and Metabolism 198615 259-278. (https:// doi.org/10.1016/S0300-595X(86)80024-X)

68 Tremblay RR \& Dube JY. Plasma concentrations of free and non-TeBG bound testosterone in women on oral contraceptives. Contraception 197410 599-605. (https://doi.org/10.1016/0010-7824(74)90099-7)

69 Loric S, Guechot J, Duron F, Aubert P \& Giboudeau J. Determination of testosterone in serum not bound by sex-hormone-binding globulin: diagnostic value in hirsute women. Clinical Chemistry 1988 34 1826-1829.

70 Déchaud H, Lejeune H, Garoscio-Cholet M, Mallein R \& Pugeat M. Radioimmunoassay of testosterone not bound to sex-steroid-binding protein in plasma. Clinical Chemistry 198935 1609-1614.

71 Azziz R, Sanchez LA, Knochenhauer ES, Moran C, Lazenby J, Stephens KC, Taylor K \& Boots LR. Androgen excess in women: experience with over 1000 consecutive patients. Journal of Clinical Endocrinology and Metabolism 200489 453-462. (https://doi. org/10.1210/jc.2003-031122)

72 Carmina E, Rosato F, Janni A, Rizzo M \& Longo RA. Relative prevalence of different androgen excess disorders in 950 women referred because of clinical hyperandrogenism. Journal of Clinical Endocrinology and Metabolism 200691 2-6. (https://doi.org/10.1210/ jc.2005-1457)

73 Escobar-Morreale HF, Asunción M, Calvo RA, Sancho J \& San Millan JL. Receiver operating characteristic analysis of the performance of basal serum hormone profiles for the diagnosis of polycystic ovary syndrome in epidemiological studies. European Journal of Endocrinology 2001145 619-624. (https://doi.org/10.1530/ eje.0.1450619)

74 Stener-Victorin E, Holm G, Labrie F, Nilsson L, Janson OP \& Ohlsson C. Are there any sensitive and specific sex steroid markers for polycystic ovary syndrome? Journal of Clinical Endocrinology and Metabolism 201095 810-820. (https://doi.org/10.1210/jc.2009-1908)

75 O'Reilly MW, Taylor AE, Crabtree NJ, Hughes BA, Capper F, Crowley RK, Stewart PM, Tomlinson JW \& Arlt W. Hyperandrogenemia predicts metabolic phenotype in polycystic ovary syndrome: the utility of serum androstenedione. Journal of Clinical Endocrinology and Metabolism 201499 1027-1036. (https:// doi.org/10.1210/jc.2013-3399)

76 Lerchbaum E, Schwetz V, Rabe Th, Giuliani A \& Obermayer-Pietsch B. Hyperandrogenemia in polycystic ovary syndrome: exploration of the role of free testosterone and androstenedione in metabolic phenotype. PLoS ONE 20149 e108263. (https://doi.org/10.1371/ journal.pone.0108263)

77 Duxbury K, Gallagher L \& Keevil B. The impact of simultaneous measurement of testosterone and androstenedione in women with suspected androgen excess. Clinical Chemistry 200753 804-805. (https://doi.org/10.1373/clinchem.2006.083782)

78 Barth JH, Field HP, Yasmin E \& Balen AH. Defining hyperandrogenism in polycystic ovary syndrome: measurement of testosterone and androstenedione by liquid chromatography-tandem mass spectrometry and analysis by receiver operator characteristic plots. European Journal of Endocrinology 2010162 611-615. (https:// doi.org/10.1530/EJE-09-0741)

79 Pasquali R, Zanotti L, Fanelli F, Mezzullo M, Fazzini A, Morselli Labate AM, Repaci A, Ribichini D \& Gambineri A. Defining hyperandrogenism in women with polycystic ovary syndrome: a challenging perspective. Journal of Clinical Endocrinology and Metabolism 2016101 2013-2022. (https://doi.org/10.1210/jc.2015-4009)

80 Longcope C. Adrenal and gonadal androgen secretion in normal females. Journal of Clinical Endocrinology and Metabolism 198615 213-228. (https://doi.org/10.1016/S0300-595X(86)80021-4)

81 Strott CA. Sulfonation and molecular action. Endocrine Reviews 2002 23 703-732. (https://doi.org/10.1210/er.2001-0040)

82 Rosenfeld RS, Rosenberg BJ, Fukushima DK \& Hellman L. 24-hour secretory patterns of dehydro-epiandrosterone and dehydroepiandrosterone sulfate. Journal of Clinical Endocrinology and Metabolism 197540 850-855. (https://doi.org/10.1210/jcem-40-5850)

83 Haning RV Jr, Flood CA, Hackett RJ, Loughlin JS, McLure N \& Longcope C. Metabolic clearance rate of dehydroepiandrosterone sulfate, its metabolism to testosterone, and its intrafollicular metabolism to dehydroepiandrosterone, androstenedione, testosterone, and dihydrotestosterone in vivo. Journal of Clinical Endocrinology and Metabolism 199172 1088-1095. (https://doi. org/10.1210/jcem-72-5-1088)

84 Nakamura Y, Hornsby PJ, Casson P, Morimoto R, Satoh F, Xing Y, Kennedy MR, Sasano H \& Rainey WE. Type 5 17ß-hydroxysteroid dehydrogenase (AKR 1C3) contributes to testosterone production in the adrenal reticularis. Journal of Clinical Endocrinology and Metabolism 200994 2192-2198. (https://doi.org/10.1210/jc.2008-2374) 
85 Labrie F, Bélanger A, Cusan L, Gomez JL \& Candas B. Marked decline in serum concentrations of adrenal C19 sex steroid precursors and conjugated androgen metabolites during aging. Journal of Clinical Endocrinology and Metabolism 199782 2396-2402. (https://doi. org/10.1210/jcem.82.8.4160)

86 Noordam C, Dhir V, McNelis JC, Schlereth F, Hanley NA, Krone N, Smeitink JA, Smeets R, Sweep F, Claahsen-van der Grinten HL et al. Inactivating PAPSS2 mutations in a patient with premature pubarche. New England Journal of Medicine 2009360 2310-2318. (https://doi. org/10.1056/NEJMoa0810489)

87 Goodarzi MO, Carmina E \& Azziz R. DHEA, DHEAS and PCOS. Journal of Steroid Biochemistry and Molecular Biology 2015145 213-225. (https://doi.org/10.1016/j.jsbmb.2014.06.003)

88 Maliqueo M, Sir-Petermann T, Perez V, Echiburú B, de Guevara AL, Gálvez C, Crisosto N \& Azziz R. Adrenal function during childhood and puberty in daughters of women with polycystic ovary syndrome. Journal of Clinical Endocrinology and Metabolism 200994 3282-3288. (https://doi.org/10.1210/jc.2009-0427)

89 Moghetti P, Castello R, Negri C, Tosi F, Spiazzi GG, Brun E, Balducci R, Toscano V \& Muggeo M. Insulin infusion amplifies 17 alpha-hydroxycorticosteroid intermediates response to adrenocorticotropin in hyperandrogenic women: apparent relative impairment of 17,20-lyase activity. Journal of Clinical Endocrinology and Metabolism $1996 \mathbf{8 1} 881-886$.

90 Zhang LH, Rodriguez H, Ohno S \& Miller WL. Serine phosphorylation of human P450c17 increases 17,20-lyase activity: implications for adrenarche and the polycystic ovary syndrome. PNAS 199592 10619-10623. (https://doi.org/10.1073/ pnas.92.23.10619)

91 l'Allemand D, Penhoat A, Lebrethon MC, Ardèvol R, Baehr V, Oelkers $\mathrm{W} \&$ Saez JM. Insulin-like growth factors enhance steroidogenic enzyme and corticotropin receptor messenger ribonucleic acid levels and corticotropin steroidogenic responsiveness in cultured human adrenocortical cells. Journal of Clinical Endocrinology and Metabolism 199681 3892-3897.

92 Arslanian SA, Lewy V, Danadian K \& Saad R. Metformin therapy in obese adolescents with polycystic ovary syndrome and impaired glucose tolerance: amelioration of exaggerated adrenal response to adrenocorticotropin with reduction of insulinemia/insulin resistance. Journal of Clinical Endocrinology and Metabolism 200287 1555-1559. (https://doi.org/10.1210/jcem.87.4.8398)

93 Azziz R, Ehrmann DA, Legro RS, Fereshetian AG, O’Keefe M \& Ghazzi MN. Troglitazone decreases adrenal androgen levels in women with polycystic ovary syndrome. Fertility and Sterility $2003 \mathbf{7 9}$ 932-937. (https://doi.org/10.1016/S0015-0282(02)04914-2)

94 Romualdi D, Giuliani M, Draisci G, Costantini B, Cristello F, Lanzone A \& Guido M. Pioglitazone reduces the adrenal androgen response to corticotropin-releasing factor without changes in ACTH release in hyperinsulinemic women with polycystic ovary syndrome. Fertility and Sterility $2007 \mathbf{8 8} 131-138$. (https://doi.org/10.1016/j. fertnstert.2006.11.076)

95 Abbott DH, Zhou R, Bird IM, Dumesic DA \& Conley AJ. Fetal programming of adrenal androgen excess: lessons from a nonhuman primate model of polycystic ovary syndrome. Endocrine Development 200813 145-158.

96 Brennan K, Huang A \& Azziz R. Dehydroepiandrosterone sulfate and insulin resistance in patients with polycystic ovary syndrome. Fertility and Sterility 200991 1848-1852. (https://doi.org/10.1016/j. fertnstert.2008.02.101)

97 Kumar A, Magoffin D, Munir I \& Azziz R. Effect of insulin and testosterone on androgen production and transcription of SULT2A1 in the NCI-H295R adrenocortical cell line. Fertility and Sterility 2009 92 793-797. (https://doi.org/10.1016/j.fertnstert.2008.05.076)

98 Baculescu N, Haydar S, Gheorghiu M, Radian S, Lautier C, Poiana C, Pugeat M \& Grigorescu F. Genetic susceptibility for adrenal hyperandrogenism in polycystic ovary syndrome. European Society of Endocrinology Annual Congress 201749 GP137.

99 Moran C, Azziz R, Carmina E, Dewailly D, Fruzzetti F, Ibanez L, Knochenhauer ES, Marcondes JA, Mendonca BB, Pignatelli D et al. 21-Hydroxylase-deficient nonclassic adrenal hyperplasia is a progressive disorder: a multicenter study. American Journal of Obstetrics and Gynecology 2000183 1468-1474. (https://doi. org/10.1067/mob.2000.108020)

100 Bidet M, Bellanné-Chantelot C, Galand-Portier MB, Tardy V, Billaud L, Laborde K, Coussieu C, Morel Y, Vaury C, Golmard JL et al. Clinical and molecular characterization of a cohort of 161 unrelated women with nonclassical congenital adrenal hyperplasia due to 21-hydroxylase deficiency and 330 family members. Journal of Clinical Endocrinology and Metabolism 200994 1570-1578. (https:// doi.org/10.1210/jc.2008-1582)

101 Morel Y \& Tardy V. Molecular genetics of 21-hydroxylase deficient adrenal hyperplasia. In Androgen Excess Disorders in Women, pp 159-172. Eds R Azziz, JE Nestler \& D Dewailly. Lippincott-Raven, 1997.

102 Forest MG, Pugeat M, Monneret MP, Rigaud C, David M \& Morel Y. Normative data for the response of plasma 21-deoxycortisol to ACTH stimulation: efficient screening test for heterozygocy of 21-hydroxylase deficiency in the general population. Hormone Research 199441 110-118.

103 Fiet J, Gueux B, Gourmelen M, Kuttenn F, Vexiau P, Couillin P, Pham-Huu-Trung MT, Villette JM, Raux-Demay MC, Galons H et al. Comparison of basal and adrenocorticotropin-stimulated plasma 21- deoxycortisol and 17-hydroxyprogesterone values as biological markers of late-onset adrenal hyperplasia. Journal of Clinical Endocrinology and Metabolism 198866 659-667. (https://doi. org/10.1210/jcem-66-4-659)

104 Speiser PW, Knochenhauer ES, Dewailly D, Fruzzetti F, Marcondes JA \& Azziz R. A multicenter study of women with nonclassical congenital adrenal hyperplasia: relationship between genotype and phenotype. Molecular Genetics and Metabolism 200071 527-534. (https://doi.org/10.1006/mgme.2000.3036)

105 New MI. Extensive clinical experience: nonclassical 21-hydroxylase deficiency. Journal of Clinical Endocrinology and Metabolism 200691 4205-4214. (https://doi.org/10.1210/jc.2006-1645). (Erratum in Journal of Clinical Endocrinology and Metabolism 200792 142)

106 Young J, Tardy V, Brac de la Perrière A, Bachelot A \& Morel Y. Consensus of French Endocrine Society on female hyperandrogenism. Detection and management of late-onset 21-hydroxylase deficiency in women with hyperandrogenism. Under the direction of the French Society of Endocrinology. Annals of Endocrinology 201071 14-18. (https://doi.org/10.1016/j. ando.2009.12.009)

107 Pretorius E, Arlt W \& Storbeck KH. A new dawn for androgens: novel lessons from 11-oxygenated C19 steroids. Molecular and Cellular Endocrinology 2017441 76-85. (https://doi.org/10.1016/j. mce.2016.08.014)

108 Jonathan L, Quansona JL, Stander MA, Pretorius E, Jenkinson C, Angela E, Taylor AE \& Storbeck KH. High-throughput analysis of 19 endogenous androgenic steroids by ultra-performance convergence chromatography tandem mass spectrometry. Journal of Chromatography 20161031 131-138.

109 O'Reilly MW, Kempegowda P, Jenkinson C, Taylor AE, Quanson JL, Storbeck KH \& Arlt W. 11-oxygenated C19 steroids are the predominant androgens in polycystic ovary syndrome. Journal of Clinical Endocrinology and Metabolism 2017102 840-848. (https://doi. org/10.1210/jc.2016-3285)

110 O'Reilly MW, Kempegowda P, Walsh M, Taylor AE, Manolopoulos KN, Allwood JW, Semple RK, Hebenstreit D, Dunn WB, Jeremy W et al. AKR1C3-mediated adipose androgen generation drives lipotoxicity in women with polycystic ovary 
syndrome. Journal of Clinical Endocrinology and Metabolism 2017102 3327-3339. (https://doi.org/10.1210/jc.2017-00947)

111 Stenman UH. Standardization of hormone determinations. Best Practice and Research Clinical Endocrinology and Metabolism 201327 823-830. (https://doi.org/10.1016/j.beem.2013.10.007)

112 International Organization for Standardization (ISO). ISO15193: in vitro diagnostic medical devices - measurement of quantities in samples of biological origin - requirements for content and presentation of reference measurement procedures. (available at: http://www.iso.org/iso/home/store/catalogue_tc/catalogue_detail. htm?csnumber_42021). Accessed on December 2012.

113 Sturgeon CM. External quality assessment of hormone determinations. Best Practice and Research Clinical Endocrinology and Metabolism 201327 803-822. (https://doi.org/10.1016/j. beem.2013.08.009)

114 Rosner W \& Vesper H. On behalf of the Endocrine Society and the endorsing organizations. Toward excellence in testosterone testing: a consensus statement. Journal of Clinical Endocrinology and Metabolism 201095 4542-4548. (https://doi.org/10.1210/jc.2010-1314)

115 CDC Hormone Standardization Project. Standardization of serum total testosterone measurements. (available at: http://www.cdc.gov/ labstandards/pdf/hs/HoSt_Protocol.pdf). Accessed on December 2012.

116 Goldman AL, Bhasin S, Wu FCW, Krishna M, Matsumoto AM \& Jasuja R. A reappraisal of testosterone's binding in circulation: physiological and clinical implications. Endocrine Reviews 201738 302-324. (https://doi.org/10.1210/er.2017-00025)

Received 24 September 2017

Revised version received 7 February 2018

Accepted 16 February 2018 